\title{
PERILAKU PENGGUNAAN ALAT PELINDUNG DIRI PADA PETANI SAYUR
}

\author{
Behavior of Vegetable Farmers in Use Personal Protective Equipment
}

\section{Gracia Victoria Souisa ${ }^{* *}$}

Claudya A.

Lekatompessy '

\section{Adriana Ritje Nendissa ' \\ I Program Studi Kesehatan Masyarakat, Fakultas Kesehatan, Universitas Kristen Indonesia, Maluku, Indonesia \\ *email: souisagracia@gmail.com}

\section{Kata Kunci:}

Pengetahuan

Minat

Pembalut

\section{Keywords:}

Personal Protective Equipment Farmers

\begin{abstract}
Abstrak
Latar Belakang : Petani dalam mengolah lahan dan tanaman membutuhkan pestisida untuk memberantas hama dan gulma. Pestisida merupakan bahan yang telah banyak memberikan manfaat untuk keberlangsungan dunia produksi pertanian. Banyaknya organisme pengganggu tumbuhan yang dapat menurunkan hasil panen, dapat diminimalisir dengan pestisida, namun disisi lain pestisida dapat membahayakan kesehatan diri petani. Untuk mencegah bahaya akibat menggunakan pestisida terhadap diri pentani maka harus menggunakan APD secara lengkap dan tepat. Tujuan dari penelitian ini adalah untuk mengetahui faktor apa saja yang berhubungan dengan penggunaan alat pelindung diri pada petani pengguna pestisida di Dusun Taeno tahun 2019

Metode : Penelitian ini merupakan penelitian analitik, dengan pendekatan crosssectional. Sampel penelitian ini berjumlah 105 orang petani. Pengumpulan data menggunakan kuesioner, wawancara dan observasi. Data yang diperoleh kemudian diolah dengan uji statistik chi-square.

Hasil : Berdasarkan uji statistik bivariat variabel pengetahuan berhubungan dengan penggunaan APD, variabel sikap tidak berhubungan dengan penggunaan APD, dan variabel tindakan berhubungan dengan penggunaan APD. Hasil penelitian menunjukan bahwa variabel yang berhubungan dengan penggunaan APD yaitu variabel pengetahuan $(\rho=0,025)$ dan variabel tindakan $(\rho=0,015)$. Variabel yang tidak berhubungan yaitu variabel sikap $(\rho=0,137)$.

Kesimpulan : Variabel pengetahuan dan tindakan berhubungan dengan penggunaan APD
\end{abstract}

\footnotetext{
Abstract

Background of Study : Farmers in the processing of land and plants need pesticides to eradicate pests and weeds. Pesticide is a material that has many benefits for the sustainability of the world of agricultural production. Many plant destruction organisms that can reduce yields, can be minimized with pesticides, but on the other hand pesticides can harm the health of the farmers. To prevent the danger of using pesticides against self-purification, then must use the personal protective equipment (PPE) in complete and precise. The purpose of this research is to determine what are the factors related to the use of personal protective equipment on pesticide user farmers in Taeno village in 2019.

Methods : This research is analytical research, with a cross-sectional approach. This research sample amounted to 105 farmers. Data collection using questionnaires, interview and observation. The Data obtained is then processed with a statistical test of chi-square.

Results : Based on statistical test bivariate of knowledge variables associated with the use of APD, the attitude variables are not associated with the use of the PPE, and the action variables are associated with the use of the PPE. The results showed that the variables associated with the use of PPE are variable knowledge $(\rho=0.025)$ and action variables $(\rho=0.015)$. The unrelated variables are the attitude variables $(\rho=0.137)$. Conclusion : knowledge and action variables associated with the use of PPE.
} 


\section{PENDAHULUAN}

Petani merupakan kelompok kerja terbesar di Indonesia. Angkatan kerja yang bekerja pada sektor pertanian masih berjumlah sekitar $40 \%$ dari angkatan kerja. Banyak wilayah Kabupaten di Indonesia yang mengandalkan pertanian, termasuk perkebunan sebagai sumber penghasilan utama daerah. Menurut data International Labour Organization (ILO), penyebab kematian yang berhubungan dengan pekerjaan sebesar $34 \%$ adalah penyakit kanker, 25\% kecelakaan, $21 \%$ penyakit saluran pernafasan, $15 \%$ penyakit kardiovaskuler dan 5\% disebabkan oleh faktor yang lain (Kementerian Kesehatan Republik Indonesia, 2014).

Meningkatnya kebutuhan masyarakat akan bahan-bahan pokok menyebabkan petani mulai mencari cara untuk meningkatkan hasil tanaman, salah satunya dengan meminimalkan hama yang menyerang tanaman dengan menggunakan obat kimia pembasmi hama tanaman seperti pestisida, karena tanaman yang sudah terserang hama akan berdampak pada kerusakan tanaman yang berakibat turunnya nilai jual bahkan sampai mengalami gagal panen. Walaupun memberi dampak baik akan hasil tanaman, pestisida juga dapat memberikan dampak buruk pada kesehatan petani dan juga pencemaran pada lahan pertanian (Shobib, Yuantari and Suwandi, 2013).

Pestisida memiliki beberapa dampak negatif bagi penggunanya jika tidak menggunakan alat pelindung diri. Hal tersebut berkaitan dengan kegiatan petani seperti menyemprot, menyiapkan perlengkapan untuk menyemprot, termasuk mencampur pestisida, mencuci peralatan atau pakaian yang digunakan untuk menyemprot, membuang rumput dari tanaman, mencari hama, dan memanen (Kurniasih, Setiani and Nugraheni, 2013). Dampak bagi kesehatan dapat terjadi melalui kulit, pernafasan dan pencernaan yaitu berupa keracunan akut dan kronis. Gejala keracunan akut pestisida seperti sakit kepala, mual, muntah, bahkan beberapa pestisida dapat menimbulkan iritasi kulit dan kebutaan. Pada keracunan kronis tidak mudah dideteksi karena efeknya tidak segera dirasakan (Marsaulina and Wahyuni, 2007).

Petani di Dusun Taeno mengusahakan jenis-jenis sayuran seperti kacang panjang, buncis, kangkung, ketimun, kacang tanah, terong, kol, cabe, tomat, bawang merah, sawi, labu siam, jagung, dan ubi-ubian. Petani menggunakan penyemprotan pestisida sebanyak 3 kali yakni 12 hari setelah bibit ditanam, 18-24 hari kemudian, dan 15 hari sebelum panen. Jumlah petani yang bekerja pada gabungan kelompok tani (gapoktan) yaitu 144 orang yang terbagi atas 15 kelompok kecil. Hasil observasi dan wawancara terhadap ketua kelompok gabungan tani menunjukan bahwa ada petani ada yang tidak menggunakan Alat Pelindung Diri seperti saat melakukan kegiatan penyemprotan pestisida bahkan ada yang merokok saat melakukan kegiatan penyemprotan padahal telah tersedia Alat Pelindung Diri yang diberikan oleh petugas penyuluh pertanian. Keluhan kesehatan seperti mual dan pusing sering diabaikan petani padahal akan berdampak jangka panjang dan menurunkan produktivitas petani. Tujuan penelitian ini adalah untuk mengetahui faktor yang berhubungan dengan perilaku penggunaan APD oleh petani sayur di Dusun Taeno.

\section{METODOLOGI}

Penelitian ini merupakan jenis penelitian Analitik dengan menggunakan pendekatan cross sectional untuk mengetahui hubungan antara variabel dependen (penggunaan alat pelindung diri) dan variabel independen (pengetahuan, sikap dan tindakan). Lokasi penelitian ini dilakukan di Dusun Taeno, pada bulan Juli hingga Agustus 2019. Populasi pada penelitian ini adalah semua petani yang menggunakan pestisida yaitu sebanyak I44 orang petani, sampel penelitan berjumlah 105 petani (menggunakan rumus slovin).

Metode sampling menggunakan simple random sampling dengan kriteria

inklusi : bersedia menjadi reponden, responden merupakan petani sayur yang menggunakan pestisida, 
lama berprofesi sebagai petani $\geq 2$ tahun. Instrumen yang digunakan dalam penelitian ini adalah kuesioner dan observasi, data yang dikumpulkan berdasarkan penelitian yang akan dilakukan yaitu data primer dan sekunder. Data yang diperoleh dari hasil observasi dan kuesioner dilapangan diolah secara manual dan disajikan dalam bentuk tabel dan disertai dengan penjelasan. Analisis data dilakukan untuk mempermudah interpretasi dan menguji hipotesis penelitian tersebut yaitu analisis univariat dan analisis bivariat dengan tingkat kemaknaan $p<0,05$ dengan menggunakan uji Chi Square.

\section{HASIL DAN PEMBAHASAN}

\section{HASIL}

Analisis univariat dalam penelitian ini memuat karakteristik responden dan karakteristik variable penelitan. Karakteristik responden diantaranya umur, lama kerja, jenis kelamin dan tingkat pendidikan, sedangkan variable penelitian meliputi variabel dependen (penggunaan alat pelindung diri) dan variabel independen (pengetahuan, sikap dan tindakan) dan dapat dilihat pada tabel I dan 2 dibawah ini.

Tabel I. Karakteristik responden dan variable penelitian

\begin{tabular}{|c|c|c|}
\hline Karakteristik Responden & $\mathbf{n}$ & $\%$ \\
\hline Kelompok Umur (Tahun) & & \\
\hline 3 I-40 & 12 & $\mathrm{II}, 4$ \\
\hline $4 \mathrm{I}-50$ & 44 & $4 \mathrm{I}, 9$ \\
\hline $5 \mathrm{I}-60$ & 38 & 36,2 \\
\hline $6 \mathrm{I}-70$ & $\mathrm{II}$ & $\mathrm{I} 0,5$ \\
\hline Lama Kerja (Tahun) & & \\
\hline$\leq \mathrm{I0}$ & $2 \mathrm{I}$ & 20 \\
\hline II-20 & 37 & 35,2 \\
\hline $2 \mathrm{I}-30$ & 28 & 26,7 \\
\hline$\geq 3 \mathrm{I}$ & 19 & $18, \mathrm{I}$ \\
\hline Jenis Kelamin & & \\
\hline Laki-laki & 59 & 56,2 \\
\hline Perempuan & 46 & 43,8 \\
\hline Tingkat Pendidikan & & \\
\hline Tidak Sekolah & 9 & 8,6 \\
\hline SD & 56 & 53,3 \\
\hline SMP & 33 & $3 \mathrm{I}, 4$ \\
\hline SMA & 7 & 6,7 \\
\hline Variable Penelitian & & \\
\hline
\end{tabular}

\begin{tabular}{|c|c|c|}
\hline Penggunaan APD & & \\
\hline Lengkap & 32 & 30,5 \\
\hline Tidak Lengkap & 73 & 69,5 \\
\hline Pengetahuan & & \\
\hline Baik & 45 & 42,9 \\
\hline Kurang & 60 & 57,1 \\
\hline Postitif & & \\
\hline Negatif & 66 & 62,9 \\
\hline Tindakan & 39 & 37,1 \\
\hline Baik & & \\
\hline Kurang & 42 & 40 \\
\hline Total & 63 & 60 \\
\hline
\end{tabular}

Selain analisis univariat, juga dilakukan analisis bivariat untuk melihat hubungan antara variabel independen dan variabel dependen Hasil analisis disajikan dalam tabel $2-4$, sebagai berikut.

Tabel 2. Hubungan Antara Tingkat Pengetahuan Dengan Penggunaan APD Pada Petani Pengguna Pestisida Di Dusun Taeno

\begin{tabular}{|c|c|c|c|c|c|c|c|c|}
\hline \multirow{3}{*}{ No } & \multirow{3}{*}{ Pengetahuan } & \multicolumn{4}{|c|}{ Penggunaan APD } & \multirow{2}{*}{\multicolumn{2}{|c|}{ Jumlah }} & \multirow{3}{*}{$\begin{array}{c}P \\
\text { Value }\end{array}$} \\
\hline & & \multicolumn{2}{|c|}{ Lengkap } & \multicolumn{2}{|c|}{$\begin{array}{l}\text { Tidak } \\
\text { Lengkap }\end{array}$} & & & \\
\hline & & $\mathbf{N}$ & $\%$ & $\mathbf{N}$ & $\%$ & $\mathbf{N}$ & $\%$ & \\
\hline $\mathrm{I}$ & Baik & 8 & 17,8 & 37 & 82.2 & 45 & 100 & \multirow{3}{*}{0,025} \\
\hline 2 & Kurang Baik & 24 & 40 & 36 & 60 & 60 & 100 & \\
\hline \multicolumn{2}{|c|}{ Total } & 32 & 30,5 & 73 & 69,5 & 105 & 100 & \\
\hline
\end{tabular}

Tabel I. menunjukan persentase terbesar pada pengetahuan baik namun penggunaan APD tidak lengkap yaitu sebanyak 37 responden (82,2\%), sedangkan persentase terkecil pada pengetahuan baik dan penggunaan APD lengkap yaitu sebanyak 8 responden (17,8\%). Hasil uji statistik diperoleh nilai $p$ value $=0,025$ karena nilai $p<\alpha$, maka $\mathrm{H}_{0}$ ditolak yang artinya ada hubungan antara pengetahuan dengan penggunaan APD pada petani pengguna pestisida di Dusun Taeno tahun 2019.

Tabel 3. Hubungan Antara Sikap Pengetahuan Dengan Penggunaan APD Pada Petani Pengguna Pestisida Di Dusun Taeno

\begin{tabular}{|c|c|c|c|c|c|c|c|c|}
\hline \multirow{3}{*}{ No } & \multirow{3}{*}{ Pengetahuan } & \multicolumn{4}{|c|}{ Penggunaan APD } & \multirow{2}{*}{\multicolumn{2}{|c|}{ Jumlah }} & \multirow{3}{*}{$\begin{array}{c}P \\
\text { Value }\end{array}$} \\
\hline & & \multicolumn{2}{|c|}{ Lengkap } & \multicolumn{2}{|c|}{$\begin{array}{l}\text { Tidak } \\
\text { Lengkap }\end{array}$} & & & \\
\hline & & $\mathbf{N}$ & $\%$ & $\mathbf{N}$ & $\%$ & $\mathbf{N}$ & $\%$ & \\
\hline $\mathrm{I}$ & Baik & 24 & 36,4 & 42 & 63,6 & 66 & 100 & \multirow{3}{*}{0,137} \\
\hline 2 & Kurang Baik & 8 & 20,5 & 31 & 79,5 & 39 & 100 & \\
\hline \multicolumn{2}{|c|}{ Total } & 32 & 30,5 & 73 & 69,5 & 105 & 100 & \\
\hline
\end{tabular}


Tabel 3. menunjukan persentase terbesar pada sikap negatif dan penggunaan tidak lengkap yaitu sebanyak 31 responden (79,5\%), sedangkan persentase terkecil pada sikap negatif dan penggunaan APD lengkap yaitu sebanyak 8 reponden $(20,5 \%)$.

Uji statistic diperoleh nilai $p$ value $=0,137$ karena nilai $p>\alpha$, maka $\mathrm{H}_{0}$ diterima yang artinya tidak ada hubungan antara sikap dengan penggunaan APD pada petani pengguna pestisida di Dusun Taeno tahun 2019.

Tabel 4. Hubungan Antara Tindakan Dengan Pengetahuan Dengan Penggunaan APD Pada Petani Pengguna Pestisida Di Dusun Taeno

\begin{tabular}{|c|c|c|c|c|c|c|c|c|}
\hline \multirow{3}{*}{ No } & \multirow{3}{*}{ Pengetahuan } & \multicolumn{4}{|c|}{ Penggunaan APD } & \multirow{2}{*}{\multicolumn{2}{|c|}{ Jumlah }} & \multirow{3}{*}{$\begin{array}{c}P \\
\text { Value }\end{array}$} \\
\hline & & \multicolumn{2}{|c|}{ Lengkap } & \multicolumn{2}{|c|}{$\begin{array}{l}\text { Tidak } \\
\text { Lengkap }\end{array}$} & & & \\
\hline & & $\mathbf{N}$ & $\%$ & $\mathbf{N}$ & $\%$ & $\mathbf{N}$ & $\%$ & \\
\hline $\mathrm{I}$ & Baik & 8 & 19 & 34 & 81 & 42 & 100 & \multirow{3}{*}{0,015} \\
\hline 2 & Kurang Baik & 24 & 38,1 & 39 & 61,9 & 63 & 100 & \\
\hline \multicolumn{2}{|c|}{ Total } & 32 & 30,5 & 73 & 69,5 & 105 & 100 & \\
\hline
\end{tabular}

Tabel 4. menunjukan persentase terbesar pada tindakan baik dan penggunaan APD baik yaitu sebanyak 34 responden (8I\%), sedangkan persentase terkecil pada tindakan baik dan penggunaan APD lengkap yaitu sebanyak 8 responden (19\%) .

Uji statistik diperoleh nilai $p$ value $=0,015$ karena nilai $p<\alpha$, maka $\mathrm{H}_{0}$ ditolak yang artinya ada hubungan antara tindakan dengan penggunaa APD pada petani pengguna pestisida di Dusun Taeno tahun 2019. Nilai phi yang diperoleh dari hasil analisis yaitu 0.203 yang artinya hubungan antara tindakan dengan penggunaan APD bersifat sangat lemah.

\section{PEMBAHASAN}

\section{Hubungan Antara Tingkat Pengetahuan dengan} Penggunaan APD pada Petani Pengguna

\section{Pestisida di Dusun Taeno}

Pengukuran terhadap pengetahuan petani dengan penggunaan APD pada petani pengguna pestisida menggunakan kuesioner. Pengetahuan responden dikategorikan "baik" jika jumlah skor yang diperoleh $>75 \%$ dari total maksimum, sementara ketegori “kurang” diberikan jika skor $\leq 75 \%$.
Berdasarkan hasil penelitian menunjukan ada hubungan yang signifikan antara pengetahuan dengan penggunaan APD pada petani pengguna pestisida di Dusun Taeno. $\mathrm{Hal}$ ini didasarkan pada hasil uji chi square yang diperoleh $\rho$ value $0,025(\rho<0,05)$. Terdapat hubungan antara pengetahuan petani dengan penggunaan APD karena pengetahuan yang baik bisa memberikan kesadaran petani dalam menggunakan APD sehingga dapat menjadi pelindung bagi petani dari resiko kontak dengan pestisida.

Hasil penelitian tentang pengetahuan terhadap pemakaian APD, menunjukan bahwa dari 105 responden yang mempunyai pengetahuan baik dan penggunaan APD secara lengkap berjumlah 8 orang $(17,8 \%)$ hal ini karena responden benar-benar mengetahui tentang penggunaan APD saat bekerja dan bahayanya jika tidak menggunakan APD. Responden yang memiliki pengetahuan kurang dan penggunaan APD secara tidak lengkap berjumlah 36 orang (60\%). Alasan responden menggunakan APD secara tidak lengkap yaitu karena kurang tersedia media informasi berupa poster dan jenis lainnya yang tersedia disekitar tempat tinggal atau tempat mereka bertani sebagai panduan dalam menggunakan APD saat bekerja dari para penyuluh pertanian atau pihak lain yang terkait.

Responden yang memiliki pengetahuan baik tetapi penggunaan APD secara tidak lengkap berjumlah 37 orang (82,2\%). Secara teori responden tahu tentang apa itu APD tetapi jika mengenai dampak, sebagian besar responden belum memahami. Hal ini disebabkan karena mereka bekerja hanya mengandalkan pengalaman pribadi sebagai sumber pengetahuan dan sebagian besar massa kerja yang $>10$ tahun berkerja tanpa menggunakan APD dan tidak mengalami penyakit yang serius akibat penggunaan pestisida dan juga dipengaruhi oleh riwayat pendidikan responden yang mayoritasnya SD. Sedangkan responden yang memiliki pengetahuan kurang tetapi penggunaan APD secara lengkap berjumlah 24 orang (40\%). Teori responden dapat dikatakan kurang tetapi saat mengaplikasikan 
APD saat bekerja, responden menggunakannya secara lengkap. Hal ini terjadi karena ketika ada penyuluhan tentang penggunaan APD, mereka menyimaknya dengan baik sehingga dapat menjadi acuan dalam penggunaan APD saat bekerja.

Penggunaan APD dapat mempengaruhi keselamatan petani karena APD menjadi pelindung dari resiko kontak dengan pestisida. APD yang dipakai petani juga harus dijaga agar tetap aman ketika digunakan. Petani harus memperhatikan arah angin ketika hendak melakukan kegiatan penyemprotan pestisida. Hal ini dikarenakan ketika arah angin berlawanan maka pestisida tersebut akan mengarah ke petani itu sendiri. Menurut Notoatmodjo (2003) pengetahuan adalah apa yang diketahui oleh seseorang tentang sesuatu hal yang didapat secara formal maupun informal. Menurut teori Lawrence Green menjelaskan bahwa pengetahuan merupakan faktor awal dari suatu perilaku yang diharapkan dan pada umumnya berkorelasi positif dengan perilaku. Berdasarkan tingkatan tahu, memahami, mengaplikasikan, analisa, sintesa, dan evaluasi yang nantinya akan mempengaruhi perilaku kesehatan yang dilakukan. Tingkat pengetahuan mencakup apa saja yang seharusnya dilakukan dan yang tidak dilakukan dalam kaitannya dengan penggunaan APD pada petani (Notoadmojo and Soekidjo, 2003).

Pengetahuan merupakan hasil dari tahu dan ini terjadi setelah orang melakukan pengindraan terhadap suatu objek tertentu (Achmadi, 20I3). Pengetahuan tidak mutlak diperoleh dari pendidikan formal saja, pengetahuan dapat diperoleh melalui pendidikan non formal dan pengetahuan juga mengandung aspek positif dan negatif. Kedua aspek ini yang menentukan sikap dan tindakan seseorang. Pengetahuan juga dapat mempengaruhi cara berpikir seseorang dalam bekerja. Petani yang mengetahui pentingnya penggunaan APD akan cenderung memakai saat bekerja, sehingga dapat meminimalisir resiko penyakit akibat kerja.

Penelitian ini sejalan dengan penelitian Darmayanti, dkk (2015), dalam penelitiannya menyatakan bahwa ada hubungan antara pengetahuan petani pengguna pestisida dengan penggunaan APD $(\rho=0,000)$. Dalam jurnal oleh Yuantari, Widiarnako and Sunoko (20l3), menyimpulkan bahwa pengetahuan yang tepat dalam menggunakan pestisida akan berpengaruh pada perilaku dan praktik yang kurang tepat pula.

Hubungan Antara Sikap dengan Penggunaan APD pada Petani Pengguna Pestisida di Dusun Taeno

Pengukuran terhadap sikap petani dengan penggunaan APD pada petani pengguna pestisida menggunakan kuesioner. Sikap responden dikategorikan "baik" jika jumlah skor yang diperoleh $60 \%$ - 100\% dari total skor maksimum. Sementara kategori “kurang " diberikan jika skor $<60 \%$.

Berdasarkan hasil penelitian menunjukan tidak ada hubungan yang signifikan antara sikap dengan penggunaan APD pada petani pengguna pestisida di Dusun Taeno. Hal ini didasarkan pada hasil uji chi square yang diperoleh $\rho$ value 0,137 ( $\rho>0,05$ ). Tidak terdapat hubungan antara sikap petani dengan perilaku penggunaan APD karena sikap merupakan kecenderungan seseorang untuk merespon terhadap sesuatu hal. Dalam hal ini, petani beranggapan bahwa APD hanya menganggu ruang gerak dan memberikan ketidaknyamanan dalam bekerja.

Hasil penelitian tentang sikap terhadap pemakaian APD menunjukan bahwa dari 105 responden yang memiliki sikap positif dan penggunaan APD secara lengkap berjumlah 24 orang $(36,4 \%)$ karena menurut responden pemakaian APD yang lengkap untuk menghindari kontak langsung dengan pestisida saat bekerja. Responden yang memiliki sikap negatif dan penggunaan APD tidak lengkap berjumlah 31 orang (79,5\%) hal ini disebabkan karena responden hanya menggunakan APD yang dianggap nyaman ketika dipakai saat bekerja dan selama ini tidak pernah mendapat kendala yang berarti.

Responden yang memiliki sikap positif tetapi penggunaan APD secara tidak lengkap berjumlah 42 
orang $(63,6 \%)$ hal ini karena APD responden berpendapat bahwa ketika menggunakan APD membuat tidak nyaman saat bekerja dan dan mereka menganggap bahwa menggunakan APD ataupun tidak menggunakan APD tidak memberikan pengaruh penting saat bekerja. Sedangkan responden yang memiliki sikap negatif tetapi penggunaan APD secara lengkap berjumlah 8 orang (20,5\%). Alasan responden menggunakan APD secara lengkap karena mereka memiliki rasa peduli terhadap kesehatan. Pengaruh teman atau orang-orang sekitar yang memberikan motivasi dalam hal penggunaan APD secara lengkap juga merupakan suatu faktor pendukung dalam responden menggunakan APD saat bekerja.

Selain pengetahuan, pengalaman dan pengaruh orang lain, budaya atau kebiasaan merupakan salah satu faktor penting yang mempengaruhi sehingga sikap seseorang terbentuk. Karena budayalah yang memberikan corak dalam kehidupan individu (Azwar, 20II). Berdasarkan observasi lansung yang dilakukan, sebagian besar petani hanya menggunakan APD yang dirasa nyaman untuk mereka bekerja seperti celana panjang, baju lengan panjang dan sepatu boots. Mereka hanya menggunakan APD tersebut agar terhindar dari sinar matahari saat bekerja. Sikap merupakan suatu bentuk kesiapan atau kesediaan untuk bertindak, dan bukan merupakan pelaksanaan motif tertentu (Notoadmojo and Soekidjo, 2003).

Pengetahuan dan pemahaman tentang penggunaan APD pada petani pada akhirnya akan diaplikasikan dalam bentuk sikap dan tindakan pada saat bekerja. Output sikap pada setiap individu dapat berbeda, jika suka atau setuju terhadap suatu objek maka akan mendekat, mencari tahu, dan bergabung, sebaliknya jika tidak suka atau tidak setuju maka akan menghindar atau menjauhi. Sikap dapat timbul dengan adanya pengetahuan dari individu. Sedangkan, pengetahuan dapat langsung mempengaruhi individu untuk berperilaku dalam menggunakan APD (Budiman and Riyanto, 2012).
Hasil penelitian ini sejalan dengan hasil penelitian Darmayanti, Tirtayasa and Saputra (2015) yang menyatakan bahwa tidak ada hubungan yang signifikan antara sikap dengan penggunaan APD dengan nilai $\rho=$ 0,796. Hasil dari data wawancara pada petani pengguna pestisida di Dusun Taeno dapat diketahui bahwa kurang adanya kesadaran dan kepedulian yang baik dari para petani untuk kesehatan mereka sendiri sehingga membuat sikap mereka menjadi acuh terhadap pentingnya menggunakan APD.

\section{Hubungan Antara Tindakan dengan Penggunaan APD pada Petani Pengguna Pestisida di Dusun Taeno}

Pengukuran terhadap tindakan petani dengan penggunaan APD pada petani pengguna pestisida menggunakan kuesioner. Tindakan responden dikatakan "baik" jika jumlah skor yang diperoleh berada dalam rentang 75\% - 100\% sedangkan kategori “kurang” diberikan jika skor yang diperoleh kurang dari $75 \%$.

Berdasarkan hasil penelitian menunjukan ada hubungan yang signifikan antara tindakan dengan penggunaan APD pada petani pengguna pestisida di Dusun Taeno. Hal ini didasarkan pada hasil uji chi square yang diperoleh $\rho$ value 0,0 5 ( $\rho<0,05)$. Terdapat hubungan antara tindakan dengan penggunaan APD karena tindakan seseorang dapat terwujud ketika memiliki sikap yang baik dalam menyikapi penggunaan APD. Hasil penelitian tentang tindakan terhadap penggunaan APD menunjukan bahwa dari 105 responden yang memiliki tindakan baik dan penggunaan APD secara lengkap berjumlah 8 orang (19\%) karena responden menghindari kontak langsung dengan pestisida dan untuk mencegah terjadinya penyakit yang disebabkan oleh pestisida. Responden yang memiliki tindakan kurang dan penggunaan APD secara tidak lengkap berjumlah 39 orang $(61,9 \%)$ hal ini disebabkan karena responden tersebut hanya nyaman dengan menggunakan APD seadanya ketika bekerja. 
Responden yang memiliki tindakan baik tetapi penggunaan APD secara tidak lengkap berjumlah 34 orang (8I\%). Alasan responden menggunakan APD secara tidak lengkap karena mereka berpendapat bahwa jika menggunakan APD saat bekerja sangat membatasi ruang gerak, mengganggu dan menghambat pekerjaan sehingga mereka tidak menggunakan secara lengkap. Penggunaan APD seperti masker sangat jarang digunakan karena responden mengaku bahwa jika menggunakan masker maka akan sulit bernafas dan hanya menggunakan pakaian yang dianggap nyaman saat bekerja seperti baju lengan panjang dan celana panjang dengan alasan agar terhindar dari sinar matahari bukan pestisida. Sedangkan responden yang memiliki tindakan kurang tetapi penggunaan APD secara lengkap berjumlah 24 orang $(38,1 \%)$ karena menurut responden, APD adalah merupakan pelindung yang paling utama saat bekerja.

Suatu sikap belum otomatis terwujud dalam suatu tindakan. Untuk terwujudnya sikap menjadi suatu perbuatan nyata diperlukan faktor pendukung atau suatu kondisi yang memungkinkan yaitu tersedianya fasilitas dalam hal ini APD pada petani. Penggunaan APD merupakan tindakan yang penting dilakukan oleh petani, karena petani memiliki perilaku untuk menjaga keselamatan dan kenyamanan dalam menjalankan tindakan saat bekerja. Tindakan dan kelengkapan penggunaan APD sangat penting karena dapat mencegah timbulnya penyakit akibat kerja dan kecelakaan kerja akibat suatu pekerjaan. Keefektifan penggunaan APD adalah terbentuk dari petani itu sendiri (Wibowo, 2010).

Secara logis sikap akan dicerminkan dalam bentuk tindakan namun tidak dapat dikatakan bahwa sikap dan tindakan memiliki hubungan yang sistematis. Suatu sikap belum tentu terwujud dalam suatu tindakan. Untuk terwujudnya sikap menjadi suatu tindakan diperlukan faktor pendukung atau suatu kondisi yang memungkinkan antara lain fasilitas dan faktor dukungan dari berbagai pihak (Notoadmojo and Soekidjo, 2003).
Penelitian ini sejalan dengan hasil penelitian Dina Ediana (20I7). Dalam penelitiannya menyatakan bahwa ada hubungan yang signifikan antara tindakan petani pengguna pestisida dengan penggunaan APD dengan nilai $\rho=0,000$. Hasil dari data wawancara dan observasi pada petani pengguna pestisida di Dusun Taeno dapat diketahui bahwa mereka melakukan penyemprotan pestisida hanya berdasarkan pengalaman yang mereka miliki dan sebagian besar memiliki sikap yang kurang patuh terhadap penggunaan APD.

\section{KESIMPULAN}

Berdasarkan hasil penelitian dan hasil analisis maka kesimpulan dari penelitian ini adalah ada hubungan antara pengetahuan dan tindakan dengan penggunaan APD pada petani pengguna pestisida; serta tidak ada hubungan antara sikap dengan penggunaan APD pada petani pengguna pestisida.

\section{UCAPAN TERIMA KASIH}

\section{REFERENSI}

I. Kementerian Kesehatan Republik Indonesia (2014) I orang pekerja di dunia meninggal setiap I5 detik karena kecelakaan kerja. Jakarta.

2. Shobib, M. N., Yuantari, M. C. and Suwandi, M. (20I3) hubungan antara pengetahuan dan sikap dengan praktik pemakaian (apd) alat pelingdung diri pada petani pengguna pestisida di desa curut kec. penawangan kab. grobogan tahun 2013. Universitas Dian Nuswantoro.

3. Kurniasih, S. A., Setiani, O. and Nugraheni, S. A. (2013) 'Faktor-faktor yang Terkait Paparan Pestisida dan Hubungannya dengan Kejadian Anemiapada Petani Hortikultura di Desa Gombong Kecamatan Belik Kabupaten Pemalang JawaTengah', Jurnal Kesehatan Lingkungan Indonesia, I2(2), pp. I32-137. 
4. Marsaulina, I. and Wahyuni, A. S. (2007) 'faktorfaktor yang berhubungan dengan keracunan pestisida pada petani hortikultura dikecamatan jorlang hataran kabupaten simalungun tahun 2005', Media Lit bang Kesehatan XVII, XVII(I).

5. Notoadmojo and Soekidjo (2003) Pendidikan Dan Perilaku Kesehatan. Jakarta: Rineka Cipta.

6. Achmadi, U. F. (20I3) Kesehatan Masyarakat: Teori dan Aplikasi. Jakarta: Rajawali Pers.

7. Darmayanti, I. D. A. A. I., Tirtayasa, K. and Saputra, K. (20I5) 'Hubungan antara tingkat pengetahuan dengan Kepatuhan Dalam menggunakan alat pelindung diri Pada petani pengguna pestisida', COPING Ners Journal, 3(3), PP. 70-75.

8. Yuantari, M. C., Widiarnako, B. and Sunoko, H. R. (2013) 'Tingkat Pengetahuan Petani dalam Menggunakan Pestisida (Studi Kasus di Desa Curut Kecamatan Penawangan Kabupaten Grobogan)', Prosiding Seminar Nasional Pengelolaan Sumberdaya Alam dan Lingkungan.

9. Azwar (20II) Sikap Manusia Teori dan Pengukurannya. Yogyakarta: Pustaka Pelajar.

10. Budiman and Riyanto, A. (2012) Kapita Selekta Kuesioner: Pengetahuan dan Sikap dalam Penelitian Kesehatan. Jakarta: Salemba Medika.

II. Wibowo (20I0) Manajemen Kinerja. Jakarta: Rajawali Press. 